\title{
Correlations Among Various Self-Consolidating Concrete Workability Responses
}

\author{
Wu-Jian Long ${ }^{1, *}$, Kamal Henri Khayat ${ }^{2}$ and Feng Xing ${ }^{1}$ \\ ${ }^{I}$ Shenzhen Durability Center for Civil Engineering, Shenzhen University, Shenzhen 518060, China \\ ${ }^{2}$ Faculty of Civil Engineering, Université de Sherbrooke, Sherbrooke J1K 2R1, Canada
}

\begin{abstract}
Self-consolidating concrete (SCC) mixtures designated for precast, prestressed applications should be highly workable to flow easily through restricted spacing and completely encapsulate reinforcements without any mechanical vibration. Key workability characteristics of SCC can be described in terms of filling ability, passing ability, and resistance to segregation. These properties are typically characterized by data that relate to specific testing methods. In general, these methods include the components required for evaluating simultaneously filling ability, passing ability, and resistance to segregation, since these properties are rather interrelated. In this investigation, 33 SCC mixtures made with various mixture proportioning parameters, including maximum size and type of aggregate, type and content of binder, and $w / \mathrm{cm}$ were evaluated. The mixtures were prepared using crushed aggregate and gravel of three different nominal sizes, $w / c m$ of 0.33 and 0.38 , and three binder compositions: Type MS cement, Type HE cement with $30 \%$ of slag replacement, and Type HE cement with $20 \%$ of Class F fly ash. Comparisons and correlations among various test results used in evaluating the workability responses obtained for these mixtures are established. This is done to highlight advantages and limitations of the various test methods that can be used to assess workability of SCC designated for prestressed applications. Appropriate combinations of test methods that can be used to assess workability of SCC at the precast plant are recommended, and ranges of acceptance of the various test methods are established.
\end{abstract}

Keywords: Mixture proportioning, workability, self-consolidating concrete, test method, prestressed concrete.

\section{INTRODUCTION}

Self-consolidating concrete (SCC) is highly flowable, non-segregating concrete that can spread into place, fill the formwork, and encapsulate the reinforcement without any mechanical consolidation [1]. SCC mixtures designated for precast, prestressed applications should be highly workable to flow easily through restricted spacing and completely encapsulate reinforcements without any mechanical vibration [2].

Filling ability (also referred to as deformability or unconfined flowability) describes the ability of the concrete to undergo changes in shape and flow around obstacles to completely encapsulate the reinforcement and fill the formwork under its own weight without any mechanical consolidation. Passing ability refers to the ability of the concrete to pass among various obstacles and narrow spacing in the formwork without blockage, in the absence of mechanical vibration. Filling capacity (also referred to as restricted deformability) is the ability of the concrete to completely fill intricate formwork or formwork containing closely spaced obstacles, such as reinforcement. The resistance to segregation (stability) describes the ability of

*Address correspondence to this author at the College of Civil Engineering, Shenzhen University, Shenzhen 518060, China;

Tel: +86-755-26535123; Fax: +86-755-26534021;

E-mails: longwj@szu.edu.cn, alainens@hotmail.com the concrete to maintain homogeneous distribution of its various constituents [1].

Workability describes the ease of mixing, placement, consolidation, and finishing of concrete [4]. The required workability for casting concrete depends on the type of construction, selected placement and consolidation methods, the complex shape of the formwork, and structural design details which affect the degree of congestion of the reinforcement. SCC should exhibit high filling ability, proper passing ability, and adequate segregation resistance. These properties are affected by the materials selection, proportioning of materials, admixtures, and application type. In the selection of material constituents and mixture proportioning of SCC for precast and prestressed structural elements, it is essential that the concrete should be selfconsolidating, i.e. it should flow into place and encapsulate the prestressing strands and reinforcing bars without segregation or blockage.

The L-box, J-Ring, and V-funnel tests are primarily employed to evaluate the narrow-opening passing ability of SCC. This can enable the evaluation of filling ability of the SCC and its resistance to dynamic segregation. On the other hand, the testing of filling capacity aims at simultaneously evaluating both the narrow-opening passing ability and selfleveling ability of the SCC. The filling caisson test provides a small-scale model of a highly congested section that is suitable to evaluate the filling capacity of SCC [3]. A 
minimum filling capacity value of $80 \%$ is considered as a lower limit to achieve proper filling of highly congested or restricted sections [4]. Despite the advantages of the filling capacity test to evaluate the ability of concrete to adequately fill restricted spacing without blockage, the test is rather cumbersome. Instead of the caisson test, the passing ability can be used in combination with slump flow to estimate the level of filling capacity of SCC. It is also important to note that the slump flow [5], J-Ring [6], and column segregation tests [7] have been standardized by ASTM for use in SCC technology.

\section{EXPERIMENTAL PROGRAM}

\subsection{Material Characteristics}

Two types of Portland cement (Type MS and Type HE) and two supplementary cementitious materials (blast-furnace slag and Class F fly ash) were used, as shown in Table $\mathbf{1 .}$ The specific gravities of the Type MS, Type HE, Class F fly ash, and blast-furnace slag are 3.14, 3.15, 2.53, and 2.95, respectively. The Blaine fineness values are 390, 530, 410, and $400 \mathrm{~m}^{2} / \mathrm{kg}$, respectively.

Three types of crushed aggregates corresponding to maximum size of aggregate (MSA) of $19 \mathrm{~mm}, 9.5 \mathrm{~mm}, 12.5$ $\mathrm{mm}$ and one type of gravel with MSA of $12.5 \mathrm{~mm}$ were selected. The aggregates conform to AASHTO $\mathrm{T} 27$ specifications. Natural siliceous sand with a specific gravity of 2.66 conforming to AASHTO T 27 specifications was used. The grading and properties of the various aggregate and sand are summarized in Table 2. The particle-size distributions of the aggregate combinations are within the AASHTO recommended limits. The grading of combined sand and coarse aggregates is plotted in Fig. (1a and $\mathbf{b})$.

Polycarboxylate-based high-range water-reducing admixture (HRWRA) complying with AASHTO M 194, Type $\mathrm{F}$ was used. An air-entraining admixture (ASTM C 260) was incorporated to obtain an initial air content of $4 \%$ to $7 \%$ in selected SCC mixtures. An organic, thickening-type VMA representative of products commonly used in the precast industry was used for the experimental program.

Table 1. Physical Properties and Chemical Composition of Cement and Supplementary Cementitious Materials

\begin{tabular}{|c|c|c|c|c|}
\hline $\begin{array}{l}\text { Cement and Supplementary } \\
\text { Cementitious Materials }\end{array}$ & $\begin{array}{l}\text { Type MS } \\
\text { Cement }\end{array}$ & $\begin{array}{c}\text { Type HE } \\
\text { Cement }\end{array}$ & $\begin{array}{l}\text { Class F } \\
\text { Fly Ash }\end{array}$ & $\begin{array}{l}\text { Blast-furnace } \\
\text { Slag }\end{array}$ \\
\hline \multicolumn{5}{|c|}{ Physical properties } \\
\hline Specific gravity & 3.14 & 3.15 & 2.53 & 2.95 \\
\hline Blaine specific surface area, $\mathrm{m}^{2} / \mathrm{kg}$ & 390 & 530 & 410 & 400 \\
\hline Passing No. $325(45 \mu \mathrm{m}), \%$ & 91 & 99 & 90 & 92 \\
\hline \multicolumn{5}{|c|}{ Chemical composition, $\%$} \\
\hline $\mathrm{SiO}_{2}$ & 21.4 & 20.0 & 52.4 & 36.0 \\
\hline $\mathrm{Al}_{2} \mathrm{O}_{3}$ & 4.6 & 5.4 & 27.2 & 10.4 \\
\hline $\mathrm{Fe}_{2} \mathrm{O}_{3}$ & 2.9 & 2.3 & 8.3 & 1.5 \\
\hline $\mathrm{CaO}$ & 63.3 & 63.5 & 4.5 & 42.9 \\
\hline $\mathrm{MgO}$ & 2.0 & 1.4 & 0.96 & 6.7 \\
\hline $\mathrm{SO}_{3}$ & 3.4 & 4.4 & 0.05 & 0.48 \\
\hline $\mathrm{K}_{2} \mathrm{O}$ & 0.94 & 1.1 & 2.33 & 0.37 \\
\hline $\mathrm{Na}_{2} \mathrm{O}$ & 0.07 & 0.15 & 0.20 & 0.17 \\
\hline $\mathrm{Na}_{2} \mathrm{O}$ eq* & 0.69 & 0.88 & 1.74 & 0.41 \\
\hline LOI & 0.98 & 0.80 & 2.73 & 0.41 \\
\hline \multicolumn{5}{|c|}{ Bogue composition, $\%$} \\
\hline $\mathrm{C}_{3} \mathrm{~S}$ & 50.0 & 54.9 & - & - \\
\hline $\mathrm{C}_{2} \mathrm{~S}$ & 23.7 & 15.8 & - & - \\
\hline $\mathrm{C}_{3} \mathrm{~A}$ & 7.4 & 10.5 & - & - \\
\hline $\mathrm{C}_{4} \mathrm{AF}$ & 8.8 & 6.9 & - & - \\
\hline
\end{tabular}

$* \mathrm{Na}_{2} \mathrm{O}$ equivalent $=\mathrm{Na}_{2} \mathrm{O}+0.64 \mathrm{~K}_{2} \mathrm{O}$ 
Table 2. Grading and Properties of Coarse Aggregate and Sand

\begin{tabular}{|c|c|c|c|c|c|}
\hline \multirow[b]{2}{*}{ Sieve Opening } & \multirow{2}{*}{$\begin{array}{c}\text { Siliceous Sand } \\
\text { o to } \text { No. } 4 \\
(0 \text { to } 4.75 \mathrm{~mm})\end{array}$} & \multicolumn{3}{|c|}{ Crushed Coarse Aggregate } & \multirow{2}{*}{$\begin{array}{c}\text { Gravel } \\
1 / 2 \text { in. to No. } 4 \\
(12.5 \text { to } 4.75 \mathrm{~mm})\end{array}$} \\
\hline & & $\begin{array}{l}3 / 4 \text { in. to } \mathrm{No.} 4 \\
(19 \text { to } 4.75 \mathrm{~mm})\end{array}$ & $\begin{array}{c}1 / 2 \text { in. to No. } 4 \\
(12.5 \text { to } 4.75 \mathrm{~mm})\end{array}$ & $\begin{array}{c}3 / 8 \text { in. to } \mathrm{No.} 8 \\
(9.5 \text { to } 2.36 \mathrm{~mm})\end{array}$ & \\
\hline 1 in. $(25 \mathrm{~mm})$ & 100 & 100 & 100 & 100 & 100 \\
\hline $3 / 4$ in. $(19 \mathrm{~mm})$ & 100 & 99 & 100 & 100 & 100 \\
\hline $1 / 2$ in. $(12.5 \mathrm{~mm})$ & 100 & 68 & 95 & 100 & 99 \\
\hline $3 / 8$ in. $(9.5 \mathrm{~mm})$ & 100 & 40 & 69 & 100 & 94 \\
\hline No. $4(4.75 \mathrm{~mm})$ & 98 & 7 & 18 & 13 & 32 \\
\hline No. $8(2.36 \mathrm{~mm})$ & 85 & 1 & 4 & 2 & 1 \\
\hline No. $16(1.18 \mathrm{~mm})$ & 72 & 1 & 3 & 2 & - \\
\hline No. $30(600 \mu \mathrm{m})$ & 55 & - & - & - & - \\
\hline No. $50(300 \mu \mathrm{m})$ & 32 & - & - & - & - \\
\hline No. $100(150 \mu \mathrm{m})$ & 9 & - & - & - & - \\
\hline Pan & 2 & 0 & 0 & 0 & 0 \\
\hline Specific gravity & 2.66 & 2.72 & 2.71 & 2.73 & 2.66 \\
\hline Absorption, $\%$ & 1.12 & 0.31 & 0.44 & 0.38 & 1.26 \\
\hline
\end{tabular}

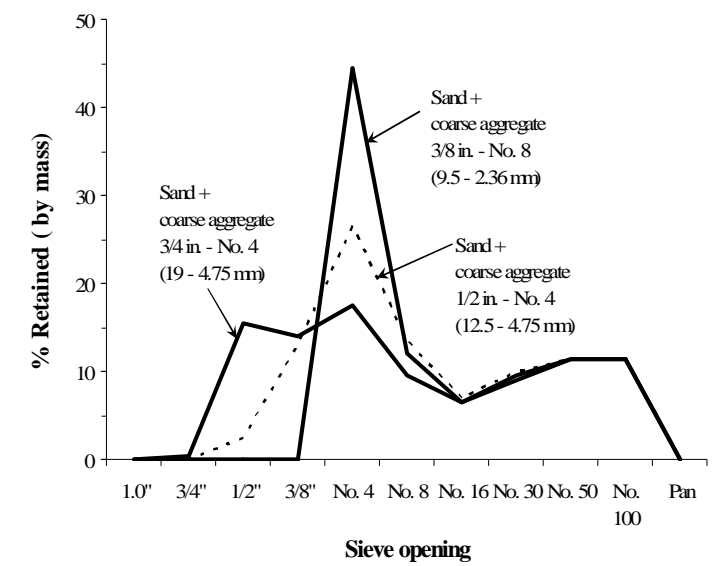

(a) Sand + crushed coarse aggregate

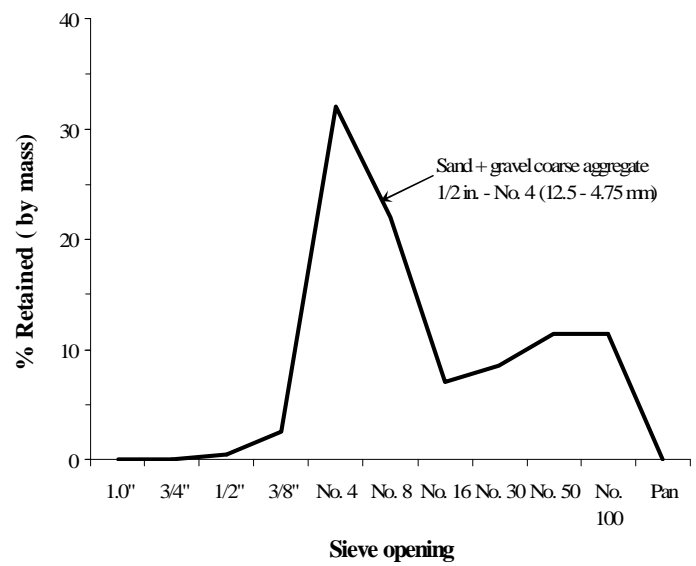

(b) Sand + gravel coarse aggregate

Fig. (1). Grading of combined aggregate retained on various sieve openings.

\subsection{Mixture Composition}

As presented in Table 3, 24 non-air entrained SCC mixtures (No. 1 to 24) were prepared to the evaluate workability of SCC. The mixtures were prepared using either crushed aggregate or gravel with MSA of 19, 12.5, and 9.5 $\mathrm{mm}$, w/cm of 0.33 and 0.38 , and three binder compositions: Type MS cement as well as Type HE cement containing either $30 \%$ slag or $20 \%$ Class F fly ash replacement of the total binder conetnt. Three air-entrained SCC (No. 25 to 27) with low w/cm were also investigated. SCC mixtures were proportioned with 460 and $480 \mathrm{~kg} / \mathrm{m} 3$ of binder. The HRWRA dosage was adjusted to achieve an initial slump flow of $680 \pm 20 \mathrm{~mm}$.
Three SCC mixtures (No. 28 to 30 ) with relatively low slump flow of $620 \pm 20 \mathrm{~mm}$ similar to mixtures No. 1 to 3 and three other mixtures (No. 31 to 33 ) with high slump flow values of $735 \pm 25 \mathrm{~mm}$ similar to mixtures No. 4 to 6 were prepared to evaluate the effect of mixture deformability on workability. Table 4 shows the testing program used for the 33 SCC mixtures prepared in this investigation.

\subsection{Mixing Sequence}

The SCC mixtures were prepared in $110-\mathrm{L}\left(3.88-\mathrm{ft}^{3}\right)$ batches using a drum mixer. The mixer was modified to promote greater shearing action of the concrete and was equipped with a speed gear to enable the simulation concrete 
Table 3. Parametric Experimental Program

\begin{tabular}{|c|c|c|c|c|c|c|c|c|c|c|}
\hline \multirow{2}{*}{ 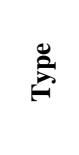 } & \multirow{2}{*}{ 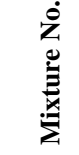 } & \multicolumn{4}{|c|}{ Aggregate Type and MSA } & \multicolumn{3}{|c|}{ Type and Content of Binder } & \multicolumn{2}{|c|}{$w / \mathrm{cm}$} \\
\hline & & $\begin{array}{c}\text { Crushed } \\
19 \mathrm{~mm}\end{array}$ & $\begin{array}{l}\text { Crushed } \\
9.5 \mathrm{~mm}\end{array}$ & $\begin{array}{l}\text { Crushed } \\
12.5 \mathrm{~mm}\end{array}$ & $\begin{array}{c}\text { Gravel } \\
12.5 \mathrm{~mm}\end{array}$ & $\begin{array}{l}\text { Type MS } \\
480 \mathrm{~kg} / \mathrm{m}^{3}\end{array}$ & $\begin{array}{l}\text { Type } \mathrm{HE}+30 \% \\
\text { Slag } 460 \mathrm{~kg} / \mathrm{m}^{3}\end{array}$ & $\begin{array}{l}\text { Type HE + 20\% } \\
\text { Fly Ash } 460 \text { kg/m }\end{array}$ & 0.33 & 0.38 \\
\hline \multirow{24}{*}{ 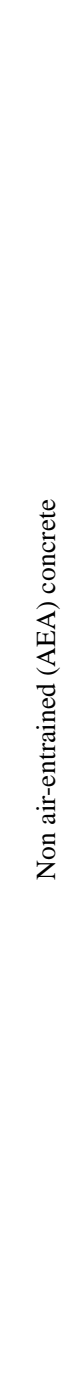 } & 1 & $\mathrm{x}$ & & & & $\mathrm{x}$ & & & $\mathrm{x}$ & \\
\hline & 2 & $\mathrm{x}$ & & & & & $\mathrm{x}$ & & $\mathrm{x}$ & \\
\hline & 3 & $\mathrm{x}$ & & & & & & $\mathrm{x}$ & $\mathrm{x}$ & \\
\hline & 4 & $\mathrm{x}$ & & & & $\mathrm{x}$ & & & & $\mathrm{x}$ \\
\hline & 5 & $\mathrm{x}$ & & & & & $\mathrm{x}$ & & & $\mathrm{x}$ \\
\hline & 6 & $\mathrm{x}$ & & & & & & $\mathrm{x}$ & & $\mathrm{x}$ \\
\hline & 7 & & $\mathrm{x}$ & & & $\mathrm{x}$ & & & $\mathrm{x}$ & \\
\hline & 8 & & $\mathrm{x}$ & & & & $\mathrm{x}$ & & $\mathrm{x}$ & \\
\hline & 9 & & $\mathrm{x}$ & & & & & $\mathrm{x}$ & $\mathrm{x}$ & \\
\hline & 10 & & $\mathrm{x}$ & & & $\mathrm{x}$ & & & & $\mathrm{x}$ \\
\hline & 11 & & $\mathrm{x}$ & & & & $\mathrm{x}$ & & & $\mathrm{x}$ \\
\hline & 12 & & $\mathrm{x}$ & & & & & $\mathrm{x}$ & & $\mathrm{x}$ \\
\hline & 13 & & & $\mathrm{x}$ & & $\mathrm{x}$ & & & $\mathrm{x}$ & \\
\hline & 14 & & & $\mathrm{x}$ & & & $\mathrm{x}$ & & $\mathrm{x}$ & \\
\hline & 15 & & & $\mathrm{x}$ & & & & $\mathrm{x}$ & $\mathrm{x}$ & \\
\hline & 16 & & & $\mathrm{x}$ & & $\mathrm{x}$ & & & & $\mathrm{x}$ \\
\hline & 17 & & & $\mathrm{x}$ & & & $\mathrm{x}$ & & & $\mathrm{x}$ \\
\hline & 18 & & & $\mathrm{x}$ & & & & $\mathrm{x}$ & & $\mathrm{x}$ \\
\hline & 19 & & & & $\mathrm{x}$ & $\mathrm{x}$ & & & $\mathrm{x}$ & \\
\hline & 20 & & & & $\mathrm{x}$ & & $\mathrm{x}$ & & $\mathrm{x}$ & \\
\hline & 21 & & & & $\mathrm{x}$ & & & $\mathrm{x}$ & $x$ & \\
\hline & 22 & & & & $\mathrm{x}$ & $\mathrm{x}$ & & & & $\mathrm{x}$ \\
\hline & 23 & & & & $\mathrm{x}$ & & $\mathrm{x}$ & & & $\mathrm{x}$ \\
\hline & 24 & & & & $\mathrm{x}$ & & & $\mathrm{x}$ & & $\mathrm{x}$ \\
\hline 首 & $25-27$ & \multicolumn{9}{|c|}{$\begin{array}{l}\text { - Air entrainment of } 4 \%-7 \% \text { and slump flow of } 680 \pm 20 \mathrm{~mm} \\
\text { - } 0.33 \mathrm{w} / \mathrm{cm} \text {, Type HE+20\% Class F fly ash, crushed aggregate MSA of } 12.5 \mathrm{~mm}\end{array}$} \\
\hline \multirow{2}{*}{ 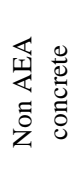 } & $28-30$ & \multicolumn{9}{|c|}{$\begin{array}{l}\text { - Low filling ability, slump flow of } 620 \pm 20 \mathrm{~mm} \\
\text { - } 0.33 \mathrm{w} / \mathrm{cm} \text {, Type HE }+30 \% \text { slag, crushed aggregate MSA of } 19 \mathrm{~mm}\end{array}$} \\
\hline & $31-33$ & \multicolumn{9}{|c|}{$\begin{array}{l}\text { - High filling ability, slump flow of } 735 \pm 25 \mathrm{~mm} \\
\text { - } 0.38 \mathrm{w} / \mathrm{cm} \text {, Type HE }+30 \% \text { slag, crushed aggregate MSA of } 19 \mathrm{~mm}\end{array}$} \\
\hline
\end{tabular}

Sand-to-total aggregate ratio (S/A) is fixed at 0.5 , by volume.

agitation to evaluate workability retention. The mixing sequence consisted of wetting the sand and coarse aggregate with half of the mixing water, followed by the addition of the binder. The HRWRA and VMA diluted with the remaining mixing water were then introduced over 30 seconds, and the concrete was mixed for 2.5 minutes. The concrete remained at rest in the mixer for 2 minutes for fluidity adjustment and to enable any large air bubbles entrapped during mixing to rise to the surface. The concrete was then remixed for 3 minutes. The fresh properties of SCC were measured at 10 and 40 minutes after cement and water contact. During that period, the concrete was agitated at $6 \mathrm{rpm}$; the drum mixer was covered during that time to prevent any water evaporation. 
Table 4. Testing Program

\begin{tabular}{|l|l|l|l|}
\hline SCC Behavior & Property & Test Method & Test Age \\
\hline \hline Filling ability & Slump flow and T-50 & ASTM C 1611 & $10 \& 40 \mathrm{~min}$ \\
\hline Passing ability & J-Ring, L-box, and V-funnel flow & ASTM C1621 & $10 \& 40 \mathrm{~min}$ \\
\hline Filling capacity & Caisson filling capacity & - & $10 \& 40 \mathrm{~min}$ \\
\hline
\end{tabular}

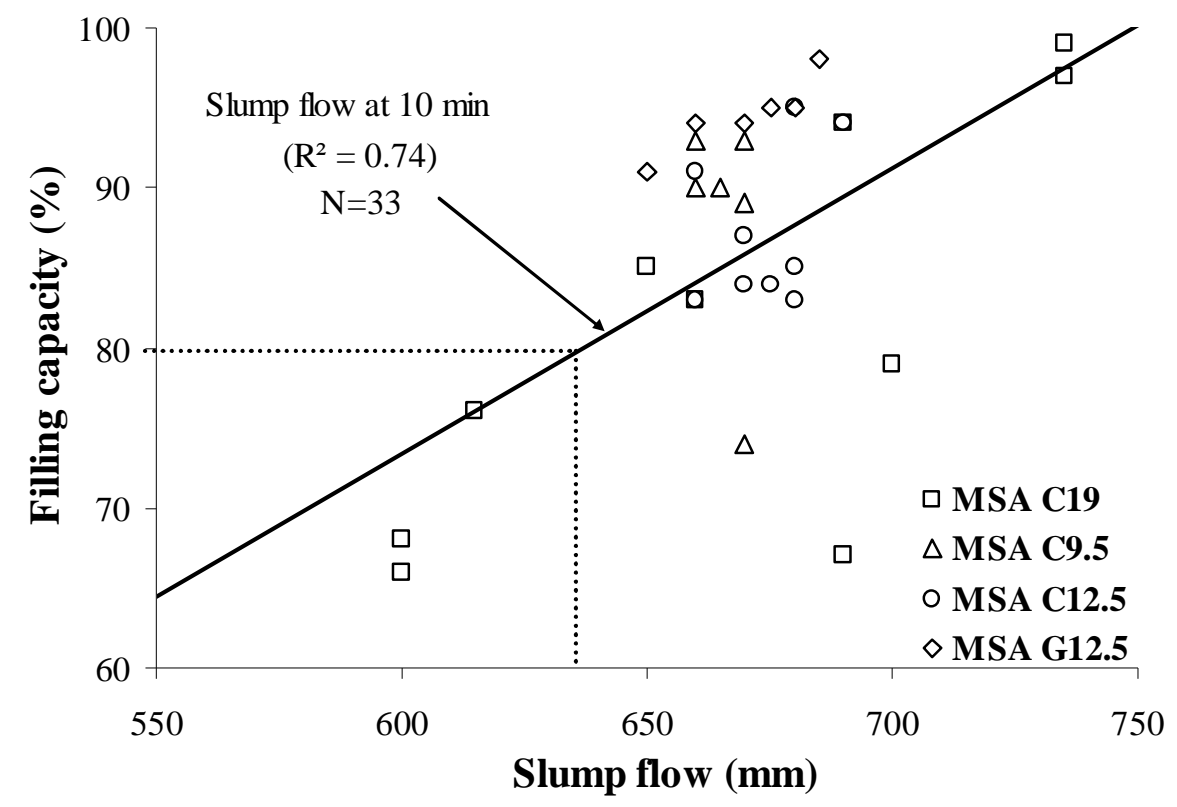

Fig. (2). Variations of filling capacity with slump flow measured at 10 minutes.

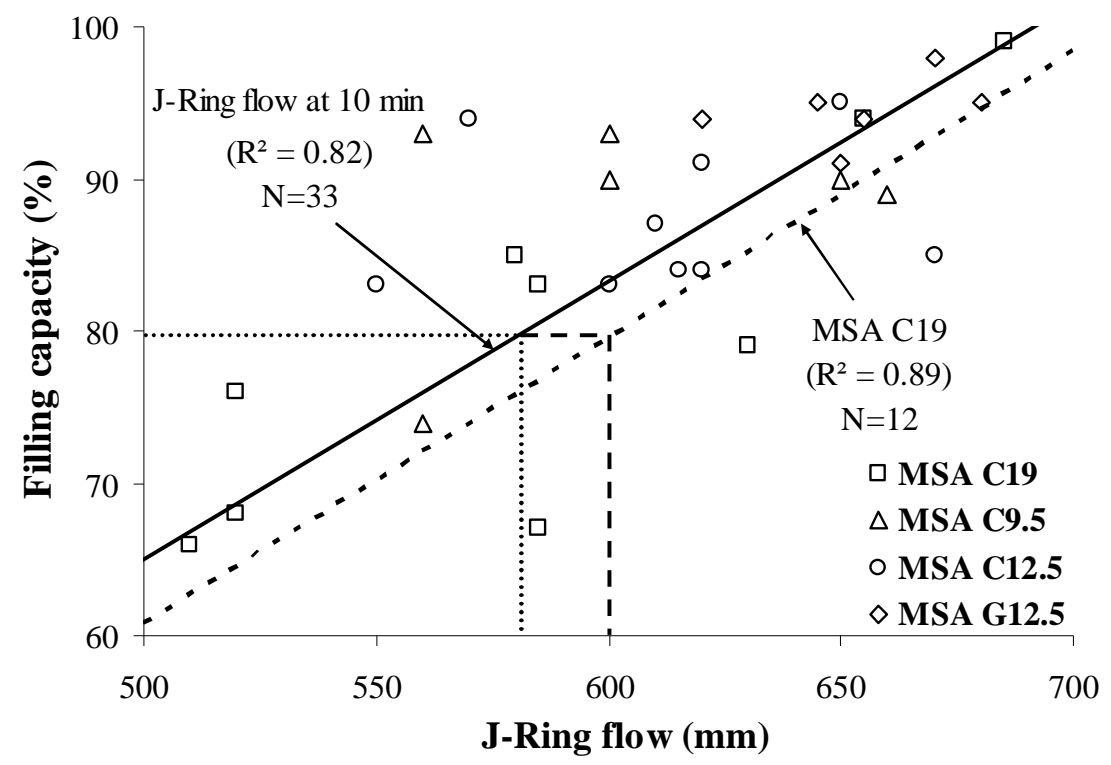

Fig. (3). Relationship between filling capacity and J-Ring flow measured at 10 minutes.

\section{TEST RESULTS AND DISCUSSION}

\subsection{Correlations between the Filling Capacity and Various Workability Characteristics}

Correlations between the filling capacity and the slump flow, J-Ring flow, spread between slump flow and J-Ring flow values (slump flow - J-Ring), as well as the L-box blocking ratio are plotted in Figs. (2, 3, 4, and 5), respectively. These relationships were established for the SCC mixtures that were sampled shortly after the end of mixing (approximately at 10 minutes of age). The mixtures had initial slump flow values varying between approximately 


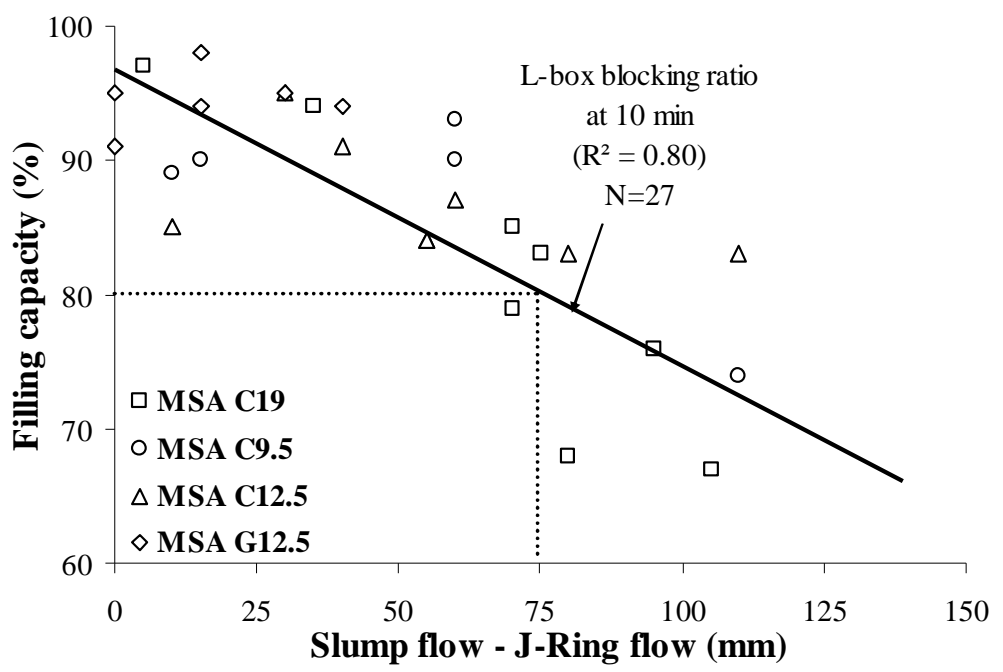

Fig. (4). Relationship between filling capacity and spread between slump flow and J-Ring flow measured at 10 minutes.

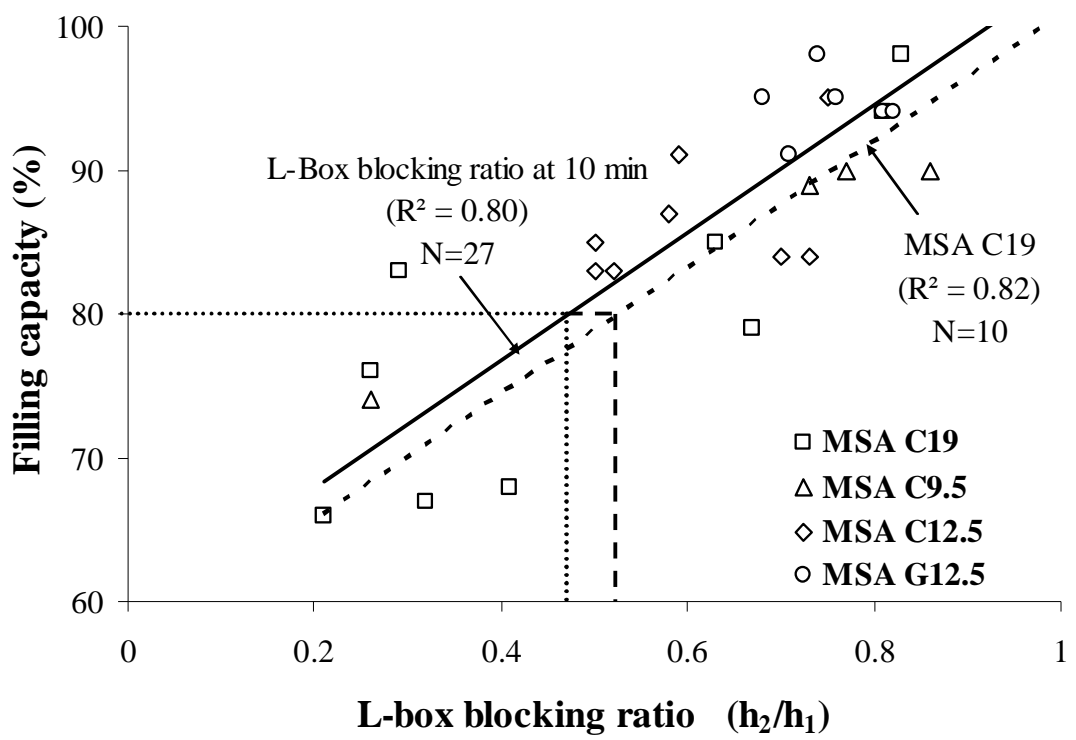

Fig. (5). Variations of filling capacity with L-box blocking ratio $\left(\mathrm{h}_{2} / \mathrm{h}_{1}\right)$.

600 and $760 \mathrm{~mm}$; however, the majority of the tested SCC had slump flow values of 660 to $700 \mathrm{~mm}$. It is important to note that all of the SCC mixtures were designed to exhibit high filling ability and proper levels of passing ability and static stability.

The increase in slump flow (non-restricted deformability) led to an increase in passing ability and filling capacity. Correlation coefficients (R2) of the relationships established between the filling capacity and slump flow, filling capacity and L-box, filling capacity and V-funnel, as well as filling capacity and J-Ring flow values were greater than 0.70 . The best correlations were obtained between the filling capacity and J-Ring flow and between the filling capacity and L-box blocking ratio with correlation coefficients of 0.82 and 0.80 , respectively, regardless of the MSA and aggregate type. Greater correlation coefficients of 0.89 and 0.82 were obtained, respectively, when considering only the SCC mixtures made with $19 \mathrm{~mm}$ crushed aggregate. This indicates that the levels of passing ability and filling capacity of the highly flowable yet stable SCC mixtures developed for precast, prestressed applications are not particularly hindered by the use of crushed aggregate of $19 \mathrm{~mm}$.

In order to secure filling capacity greater or equal to $80 \%$, which is considered here to be necessary to secure high level of filling highly congested or restricted sections, the concrete should have high level of slump flow greater than $640 \mathrm{~mm}$ and high level of restrained deformability with $\mathrm{J}$ Ring flow greater than $580 \mathrm{~mm}$. J-Ring flow should be increased to $595 \mathrm{~mm}$ for mixtures made with crushed coarse aggregate of $19 \mathrm{~mm}$, as indicated in Fig. (3). Similarly, the spread between the slump flow and J-Ring flow values can be correlated with the filling capacity values, as presented in Fig. (4). The spread should be lower than $75 \mathrm{~mm}$ to fulfill the $80 \%$ of filling capacity. As shown in Fig. (5), SCC with 
L-box blocking ratio greater than 0.5 can develop filling capacity values greater than $80 \%$. This limit can increase to 0.55 for SCC made with crushed coarse aggregate of $19 \mathrm{~mm}$.

\subsection{Combined Test Methods to Evaluate Restricted Deformability}

In general, test methods used to evaluate workability of SCC provide one workability index, which is not sufficient to adequately describe the flow behaviour of SCC. Therefore, proper combinations of various test methods can be employed to facilitate the assessment of workability and improve the quality control procedure of SCC. The establishment of proven combination of test methods that are adequate for field application can reduce time and labour as well as the number of tests required for quality control.

In general, the passing ability can be used in combination with slump flow to estimate the filling capacity of SCC [8]. This is illustrated in Fig. (6) where the filling capacity is expressed in terms of the slump flow and L-box blocking ratio $\left(h_{2} / h_{1}\right)$ and then in Fig. (7) in terms of the spread between slump flow and J-Ring flow. The region where the SCC mixtures developed minimum filling capacity of $80 \%$ is highlighted and is referred to as "Workability box". For the tested SCC in this investigation, mixtures that had filling capacities greater or equal to $80 \%$ would correspond to those with minimum slump flow and L-box blocking ratio $\left(\mathrm{h}_{2} / \mathrm{h}_{1}\right)$ values of $635 \mathrm{~mm}$ and 0.5 , respectively. A number of SCC mixtures in Fig. (7) that had slump flow values greater than $635 \mathrm{~mm}$ and spreads between slump flow and J-Ring flow below the recommended limit of $75 \mathrm{~mm}$ still ended up with filling capacity greater than $80 \%$. These mixtures were SCC made with $12.5 \mathrm{~mm}$ MSA.

The workability test results in the SCC investigation were used to derive multi-regression equations relating the filling capacity of SCC with slump flow and passing ability test results. As mentioned earlier, most of the evaluated

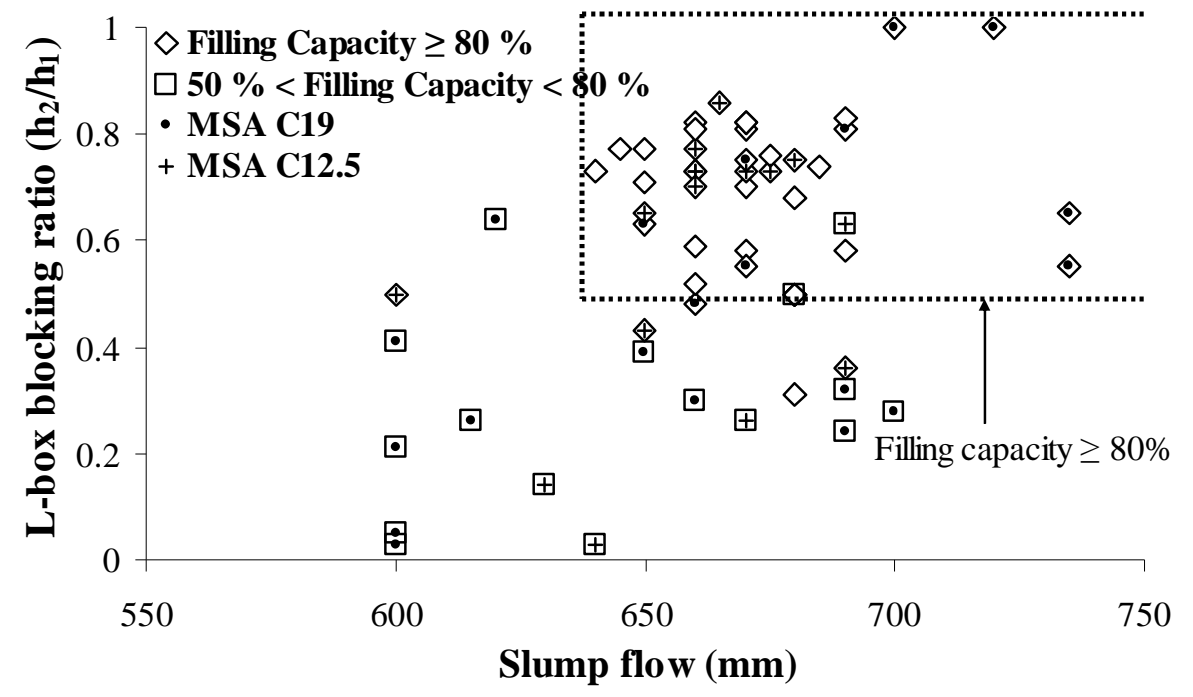

Fig. (6). "Workability box" for filling capacity as a function of L-box blocking ratio and slump flow.

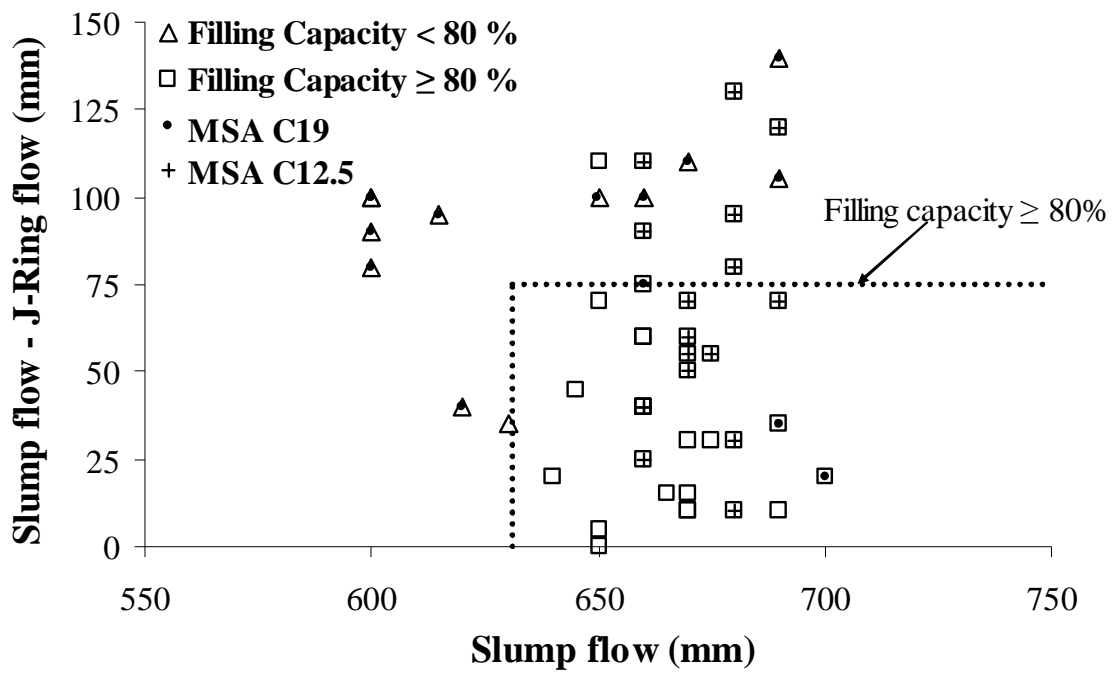

Fig. (7). Recommended lower limits of slump flow and spread between slump flow and J-Ring flow values of SCC made with crushed aggregate to secure filling capacity greater than $80 \%$. 
mixtures had initial slump flow consistency of 660 to 700 $\mathrm{mm}$. The relationships obtained with the L-box and J-Ring results can be expressed as follows:

Filling capacity $(\%)=-9.64+0.12$ slump flow $(\mathrm{mm})+$ $28.25 \mathrm{~h}_{2} / \mathrm{h}_{1}\left(\mathrm{R}^{2}=0.82\right)$

Filling capacity $(\%)=-32.82+0.05$ slump flow $(\mathrm{mm})+$ 0.14 J-Ring flow $(\mathrm{mm})\left(\mathrm{R}^{2}=0.83\right)$

The filling capacity can also be expressed as a function of the spread between slump flow and J-Ring flow diameters, as follows:

Filling capacity $(\%)=-32.82+0.19$ slump flow $(\mathrm{mm}$. $)-0.14$ \{Slump flow $(\mathrm{mm})$ - J-Ring flow $(\mathrm{mm})\}\left(\mathrm{R}^{2}=0.80\right)$

The filling capacity can also be expressed as a function of L-box blocking ratio $\left(\mathrm{h}_{2} / \mathrm{h}_{1}\right)$ and J-Ring flow diameter, as follows:

Filling capacity $(\%)=17.45+0.09$ J-Ring flow $(\mathrm{mm})+$ $19.99 \mathrm{~h}_{2} / \mathrm{h}_{1}\left(\mathrm{R}^{2}=0.85\right)$

The above multiple regression equations (Eqs. 1 to 4 ) are valid for stable mixtures with slump flow consistency of 600 to $760 \mathrm{~mm}$ prepared with crushed coarse aggregate of 19 $\mathrm{mm}, 9.5 \mathrm{~mm}$, and $12.5 \mathrm{~mm} \mathrm{MSA}$ and gravel aggregate with $12.5 \mathrm{~mm}$ MSA. These multiple regressions were established using workability data determined shortly after the end of mixing (10 minutes of age).

Contour diagrams of the filling capacity values as function of the slump flow and L-box blocking ratio are plotted in Fig. (8) based on the multiple regression correlation given in Eq. 1. For a given lower limit of blocking ratio of 0.5 , the increase in slump flow from 635 $\mathrm{mm}$ to $760 \mathrm{~mm}$ can be expected to increase the filling capacity from $80 \%$ to $95 \%$. The shaded area in Fig. (8) corresponds to a "workability region" where SCC mixtures can be expected to develop filling capacity values greater than or equal to $80 \%$ (slump flow of 635 to $760 \mathrm{~mm}$ and $\mathrm{h}_{2} / \mathrm{h}_{1}$ of 0.5 to 1.0$)$. This region coincides well with the "workability box" presented in Fig. (6) established using the actual slump flow, L-box blocking ratio, and filling capacity results.

The multiple regression correlations given in Eqs. 2 and 3 are used also to establish contour diagrams of the filling capacity of SCC as function of slump flow and J-Ring flow (Fig. 9) and slump flow and the spread between slump flow

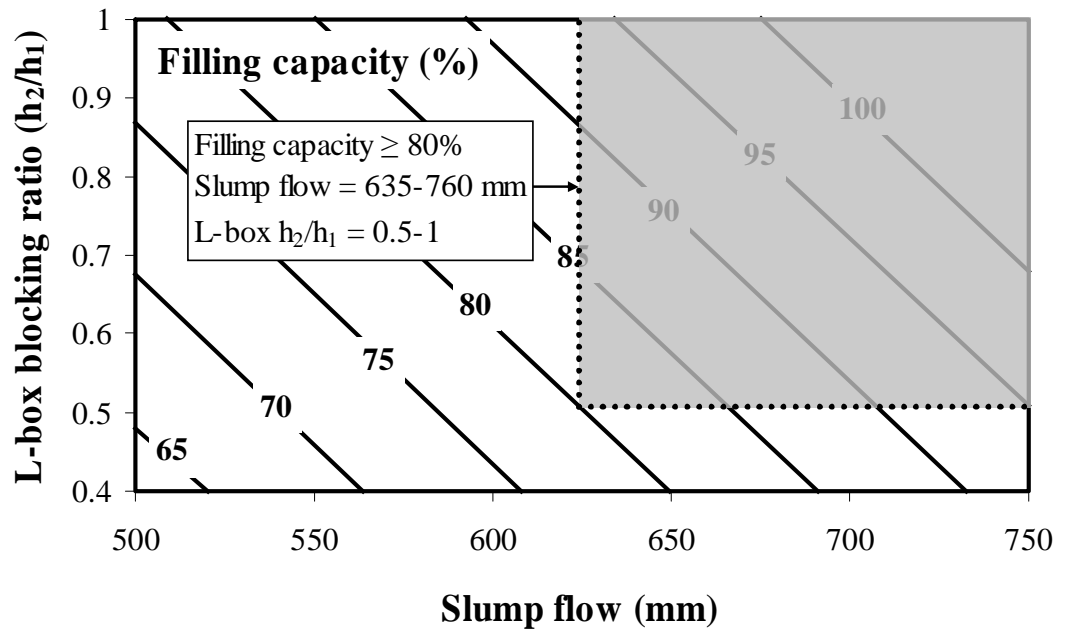

Fig. (8). Contour diagrams between filling capacity, slump flow, and L-box blocking ratio determined at 10 minutes $\left(\mathrm{R}^{2}=0.82\right)(\mathrm{Eq} .1)$.

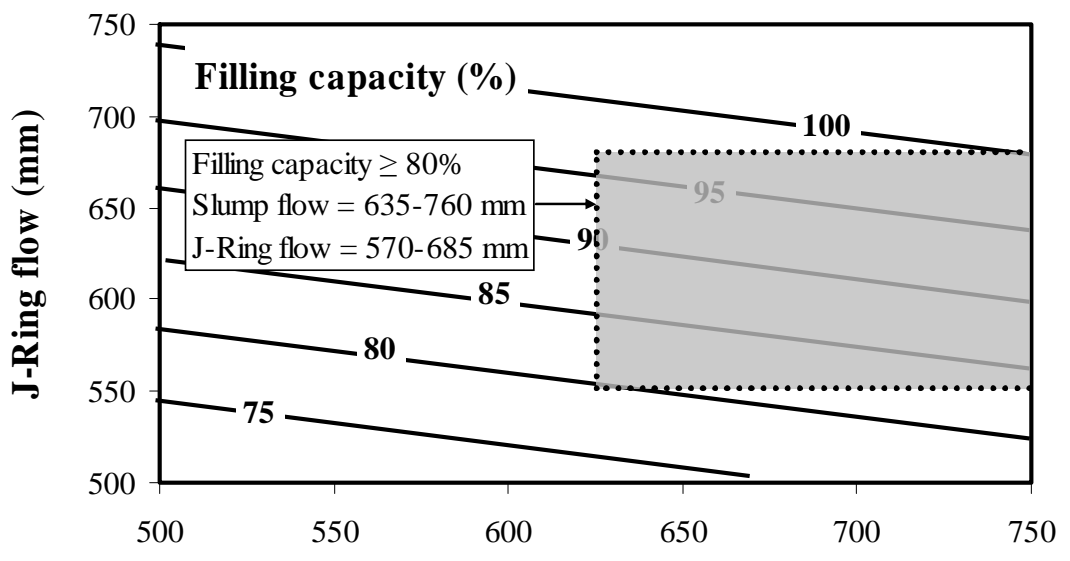

Slump flow (mm)

Fig. (9). Contour diagrams between filling capacity, slump flow, and J-Ring flow determined at 10 minutes $\left(\mathrm{R}^{2}=0.83\right)($ Eq. 2). 
and J-Ring flow values (Fig. 10). As can be observed from Fig. (11) and for a given slump flow, a decrease in J-Ring spread can lead to a decrease in filling capacity. On the other hand and for a given slump flow, an increase in the difference between slump flow and J-Ring values can lead to a reduction in filling capacity resulting from some lack in the restricted deformability across closely spaced obstacles (Fig 10).

Contour diagrams for filling capacity of SCC mixtures with different J-Ring flow and L-box blocking ratio $\left(\mathrm{h}_{2} / \mathrm{h}_{1}\right)$ values are plotted in Fig. (11). This figure also identifies a "workability region" where SCC can develop filling capacity greater or equal to $80 \%$, which corresponds to J-Ring flow of 580 to $685 \mathrm{~mm}$ and $\mathrm{h}_{2} / \mathrm{h}_{1}$ of 0.5 to 1.0 .

\section{CONCLUSIONS AND RECOMMENDATIONS}

The use of proven combinations of test methods in precast, prestressed applications is necessary to reduce time and effort required for quality control of SCC at the precasting plant. Caisson filling capacity value of $80 \%$ is considered as a lower limit for casting of densely reinforced sections, typically found in precast, prestressed applications.

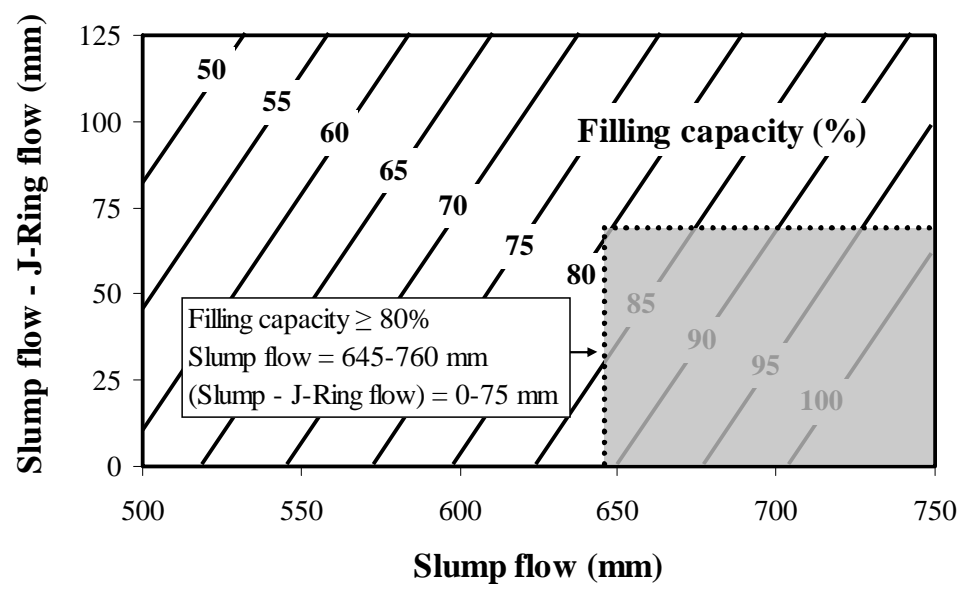

Fig. (10). Contour diagrams between filling capacity, slump flow, and (slump flow - J-Ring flow) determined at 10 minutes $\left(\mathrm{R}^{2}=0.80\right)(\mathrm{Eq} .3)$.

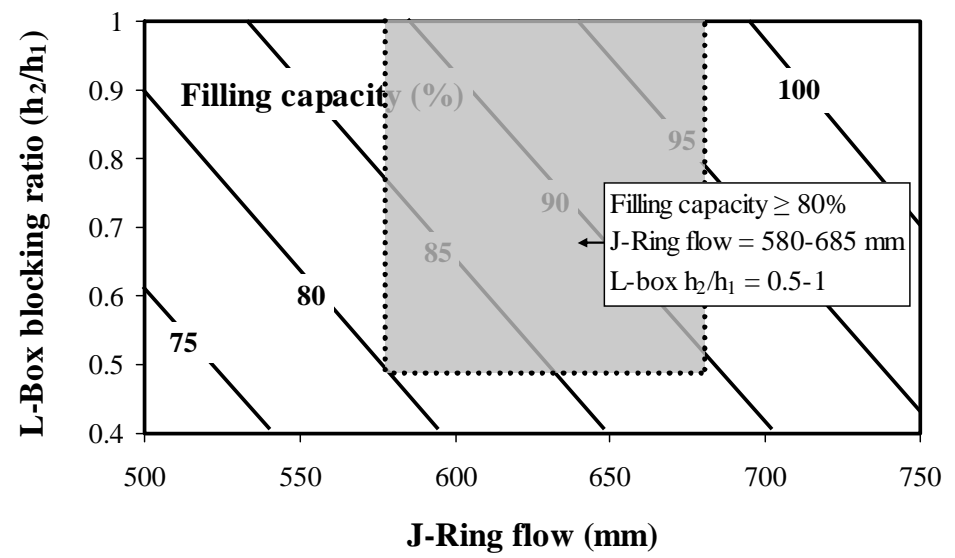

Fig. (11). Contour diagrams between filling capacity, J-Ring flow, and L-box blocking ratio determined at 10 minutes $\left(R^{2}=0.85\right)($ Eq. 4$)$.

Table 5. Combined Test Methods and Recommended Workability Values for SCC Used in Prestressed Applications

\begin{tabular}{|l|l|l|}
\hline & Combined Test Methods-I & Combined Test Methods-II \\
\hline \hline Filling ability & Slump flow $: 635-760 \mathrm{~mm}$ & $\begin{array}{l}\text { J-Ring flow }: 570-685 \mathrm{~mm} \\
\text { (Slump flow }-\mathrm{J}-\text { Ring flow) } \leq 75 \mathrm{~mm}\end{array}$ \\
\hline Passing ability & $\begin{array}{l}\text { L-box blocking } \\
\text { ratio }\left(\mathrm{h}_{2} / \mathrm{h}_{1}\right) \geq 0.5\end{array}$ & Plant use \\
\hline & Plant and laboratory use & Caisson filling capacity $\geq 80 \%$ (laboratory use) Combined test methods (I or II) \\
\hline Filling capacity &
\end{tabular}


The L-box blocking ratio $\left(\mathrm{h}_{2} / \mathrm{h}_{1}\right)$ index, J-Ring flow, or the spread between the slump flow and J-Ring flow can be combined with the slump flow to evaluate the filling capacity of SCC. The recommend combined test methods for evaluating the filling capacity of SCC are:

Combined test methods-I : Slump flow and L-box blocking ratio $\left(\mathrm{h}_{2} / \mathrm{h}_{1}\right)$

Combined test methods-II : Slump flow and J-Ring flow

Table 5 presents a set of performance specifications of SCC that can be used in precast, prestressed applications. Such specifications correspond to SCC with slump flow of 635 to $760 \mathrm{~mm}$ and, depending on the passing ability test in use, L-box blocking ratio $\left(\mathrm{h}_{2} / \mathrm{h}_{1}\right)$ greater than 0.5 , J-Ring flow of 570 to $685 \mathrm{~mm}$, and a spread in slump flow and JRing flow values lower than $75 \mathrm{~mm}$. These recommended limits should secure filling capacity level greater or equal to $80 \%$, as determined by the caisson filling capacity test.

\section{CONFLICT OF INTEREST}

Declared none.

\section{ACKNOWLEDGMENTS}

The authors gratefully acknowledge the financial support provided by the Transportation Research Board (TRB) of the National Academies (NAS-NRC) of the United States of
America for NCHRP Project 18-12, the National Natural Science Foundation of China (No. 51008197), and the National Science Fund for Distinguished Young Scholars (No. 50925829).

\section{REFERENCES}

[1] ACI Committee 237R-07, "Self-Consolidating Concrete," ACI manual of concrete practice, American Concrete Institute, Michigan, p. 30, 2008.

[2] Interim SCC Guidelines FAST Team, "Interim SCC guidelines for the use of self-consolidating concrete in precast/prestressed concrete institute member plants," Precast/Prestressed Concrete Institute: Chicago, USA, p. 148, April 2003.

[3] M. Yurugi, N. Sakata, M. Iwai, and G. Sakata, "Mix proportion of highly workable concrete," In: Proceedings of Concrete, 2000, Dundee, Scotland, 1993, pp. 579-589.

[4] K.H. Khayat, "Workability, testing, and performance of selfconsolidating concrete," ACI Mater. J., vol. 96, no. 3, pp. 346-353, 1999.

[5] ASTM C1611 / C1611M - 09b, "Standard Test Method for Slump Flow of Self-Consolidating Concrete", ASTM International: USA, 2009.

[6] ASTM C1621 / C1621M - 09b, "Standard Test Method for Passing Ability of Self-Consolidating Concrete by J-Ring", ASTM International: USA, 2009.

[7] ASTM C1610 / C1610M - 06a, "Standard Test Method for Static Segregation of Self-Consolidating Concrete Using Column Technique", ASTM International: USA, 2009.

[8] S.D. Hwang, K.H. Khayat, and O. Bonneau, "Performance-Based Specifications of Self-Consolidating Concrete Used in Structural Applications," ACI Mater. J., vol. 103, no. 2, pp. 121-129, 2006. 